\title{
Knowledge on active participation in classroom among nursing and midwifery students
}

\author{
AbebeAbera Tesema, EbrahimYimam Reta, ShekaShemsi Seid \\ School of Nursing and Midwifery, Jimma University, Ethiopia
}

\begin{tabular}{l}
\hline \hline Article Info \\
\hline Article history: \\
Received Jan 27, 2020 \\
Revised May 17, 2020 \\
Accepted Jul 28, 2020 \\
\hline
\end{tabular}

\section{Keywords:}

Classroom participation

Knowledge

Students

Strategies

\begin{abstract}
Effective learning-teaching process is ensured when students interact and actively participate in the learning process. Though most instructors stressed the value of active participation in classrooms of universities and colleges, achieving success in eliciting it appears more difficult. There is high tendency of instructors in higher institutions to cover the tasks and responsibilities of their students. The main aim of this study was to assess the knowledge of and to identify strategies for improving active participation in classroom among nursing and midwifery students. Institution based cross-sectional survey was conducted in Jimma University onrandomlyselected 126 students (81 nursing and 45 midwifery). The collected data were coded, checked and cleaned and entered into SPSS version 23 for analysis. Simple descriptive statistics was used to see the frequency distribution whereas cross-tabulation and Pearson Chi-square test were used to see the association between variables. Majority, $106(84.1 \%)$ of the students had good knowledge about the benefits of active participation in classroom and they suggested strategies to be used by regular classroom teachers to improve students' participation. Students' academic year has shown statistically significant association with their knowledge about active participation. The authors of this study strongly recommend instructors to use active learning methods and department heads need to follow teaching methods implemented by their respective faculty.
\end{abstract}

This is an open access article under the CC BY-SA license.

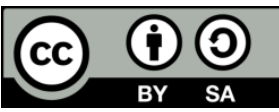

\section{Corresponding Author:}

Abebe Abera Tesema,

Department of Nursing,

Jimma University, Ethiopia

378 Jimma University, Ethiopia.

Email: abeef2011@gmail.com

\section{INTRODUCTION}

Learning is a process that requires the interaction between students and instructors in a classroom. Instructors/lecturers or teachers are considered the main players in educational process while students play the complementing role. This is because instructors bear the duty to teach, guide, motivate and shape students to become advantageous, confident and competent citizen whereas students should accept, aspire and apply the skill and knowledge entertained in the learning process [1].

Students' interaction and active participation in the classroom is crucial for achieving effective learning and teaching process. The participation level of students in classroom may range from passive to active participations. Some students may just sit quietly, taking notes, listening, doing something else, or asking questions while some of them give their opinions, or answering raised questions [2]. Liu categorized students' participation into four forms as full integration, participation in the circumstances, marginal interaction, and silent observation [3]. 
Active participation contributes to learning \& motivates students to learn. There are different ways in which students can participate some of which are by forwarding their ideas and thoughts by themselves, answering questions voluntarily and up on request, talking to peers/teachers about tasks, and completing written work and also by watching, listening, and thinking [4, 5]. Students' active involvement is fundamental action to achieve effective learning and plays significant role in the success of academic and personal development of students. When they actively participate, students will become critical thinker and enhance their intellectual development [6].

There are numerous factors that influence students' participation in learning activities. The first factor is associated with the personality of the student in which those students with high self-efficacy showed better academic achievement and participating more in the classroom. Self-efficacy helps students to be curious in learning process \& motivates them to become more active and positive thinker, highly confident, and more active [7-9]. On the contrary, students with low level of self-confidence do not make preparations before class, fear of failing to show their intelligence, fear that their answers will be criticized by the lecturers and the feelings of confusion, thus becoming less engaged in classroom discussions [10]. A study conducted by ZainalAbidin (2007) on Malaysian students' classroom participation identified five factors that influence students' participation incluing linguistic, pedagogical, cognitive, affective, and socio-cultural factors [11].

Another important factor that affects students' active participation in classroom is the characters and skills of the lecturer. Teachers/lecturers' characters such as being supportive, understanding, approachable, giving smiles and nodding for admitting the answers that are given by students, affirmative and openmindedness are among the encouraging factors [12].

The constructivists approach is newly designed to increase the participation of students in the education sector to make students more confident and productive in their future career by experiencing responsibilities in their earlier times. The proponents of constructivists approach believe that ideas should be constructed by the learners themselves so that education will be very interesting and fruitful [13].

Though most instructors stressed the value of active participation in classrooms of universities and colleges, achieving success in eliciting it appears more difficult. There is a high tendency of instructors in higher institutions to take over the tasks and responsibilities of their students. Study conducted by Smith indicates that professors talk in the classrooms almost $80 \%$ of the time [14] whereas another study conducted by Karp and Yoles shows that only about 10 in 40 students participate in discussions, from these just five of them dominate the discussion [15].

Many internal and external factors can influence the participation of students in the classroom. Engaging the students in classroom activities provides them opportunity to receive input from fellow students, to apply their knowledge and to enhance public speaking skills and it also help teachers to get a more accurate idea about the understanding level of students on the concept he/she is teaching[16].

Students' participation in classroom is a complex behavior which is influenced by several factors such as those that apply to learners in general regardless of the specific cultures they are situated in including proficiency level, motivation, character, age, etc. [17].

According to study conducted by Howard \& Baird, the power of the instructor, gender and the age discrimination of the students, the cognitive level towards classroom and also the feelings of the students are such factors which influence participation of students in the class room [18].

A study conducted on engaging students in classroom discussions also indicate that logistical issues in participation, student confidence and personality traits in participation, theinstructor'sinfluenceand suggestionsaffect students' participation. This study also recommends different action strategies to be taken like: advice, changing the seating arrangement, reinforcement, etc...to enhance the students' participation [19]. Study conducted in Malaysia also found that the size of a classroom, personalities of the instructor and students and the perception of peers influenced the students to speak up in class. Other factors that were found to influence students' classroom participation are linguistic, pedagogical, cognitive, affective, and socio-cultural factors [20]. Another study revealed that lack of knowledge about the importance of class participation, being professors who may not be well-equipped to handle class participation, not being fully attuned to the nuances of class participation management has influence on classroom participation [21]. Being in a new school atmosphere, nervousness, less content knowledge, Self-confidence or sense of security, Class size, Learning style, Comparison with other peers, Teacher's attitude anxiety about humiliation, or language problem were also other factors to influence students' class participation [22].

A study conducted by Dawit and Demis also concluded that different factors like learners related, teachers teaching methods, physical environmental and others limited students' participation in the classroom [23]. Shyness and fear of friends, language problem, teaching methods, and lack of material accessibility, sitting arrangement etc are factors identified by Adimase to influence classroom participation [24]. Howard et al. found class size to be more predictive of participation than sex [25]. The teacher's communication skills and position in a class during lesson delivery can also affect students' participation [26]. 
Currently, Ministry of education (MOE) of Ethiopia advocates the interactive type of learning i.e. use of active learning methods to help students interact with their environment and discuss issues with their colleagues freely. Even if we are using interactive type of learning methods to some extent, most of the students are dormant to participate in the classroom. This type of learning teaching approach may be contributed from different factors like extended classrooms with more students, low awareness of instructors to use interactive type of teaching, less interest of students to be active participant shows that much is left to be done.

Although active participation in learning activities is very indispensable work habit that enriches students with opportunities to learn and practice new knowledge and strategies, to explain their reasoning, to examine their thinking processes and allows teachers to scrutiny their students' thinking processes and learning, to identify learning problems, to evaluate students' academic progress, to provide cognitive support for their students, students still do not actively participate satisfactorily.

In the contemporary world, education has been transformed as to be a means for achieving ones' personal demand \& problem solving means at individual as well as in the national level which can be accomplished by implementing interactive/active learning. In the previous times, students were considered simply as passive receiver of one directional flow of information from the instructors/teachers without an active involvement of students during learning activities. This type of passive participation of students is not uncommon in most of our higher education institutions in Ethiopia. The objectives of this study is to assess the knowledge of active participation in classroom and to identifythe strategies suggested to improve participation among nursing and midwifery students of Jimma University, south west Ethiopia, 2019

\section{RESEARCH METHOD}

The study was conducted in Jimma University institute of health school of Nursing and midwifery. Jimma University is found in Jimma town which is located in Oromia region, South West Ethiopia at about $357 \mathrm{KMs}$ from Addis Ababa, capital city of Ethiopia. The climatic condition of the area is Woinedega and the altitude is $1735 \mathrm{KMs}$ above sea level. Jimma University was established in 1983 and currently has 2 institutes, 7 colleges and over 40 departments hosting more than 45,000 students on regular, summer and continuing and distance education programs. It is the pioneer university in community based education in the Ethiopian history. Currently, Jimma University Nursing and Midwifery school is running four Bachelor and two masters program in regular basis and one evening and one weekend program hosting a total of over 700 students. From these, we conducted the survey on 81 nursing and 45 midwifery (second and third year) giving a total of 126 students in the 2019/2020 academic year.Institution based cross-sectional descriptive study design was used to assess the students' knowledge of and strategies they recommend to improve active participation in the classroom. We randomly selected two-third (126) of the students by using computer generated random numbers based on the students' list in each class.

Ethical approval letter was obtained from Jimma University Nursing and midwifery school head. Oral informed consent was obtained from the respondents after briefly explaining the aim of the study. Participants were assured that if they want to refuse to participate, their lesson or dignity would not be compromised in any way since there was no relationship between participation in the study and teaching learning process. All information obtained from the students were kept confidential.Self-administered questionnaire was adopted and distributed to the students in the four categories. The collected data were coded, checked and cleaned and entered into SPSS version 23 for analysis. Descriptive statistics was used to see the frequency distribution of the students by their socio-demographic characteristics, knowledge about the benefits of active participation in classroom, and strategies they suggest to be used by regular classroom teachers to improve students' participation. We did cross tabulation and Pearson chi-square test to see the association between students' knowledge and socio-demographic characteristics. Finally, the result was presented by using narrative texts, tables and figures.

\section{RESULTS}

\subsection{Socio-demographic characteristics}

In this study a total of 126 students were involved. From these 126 respondents $65(51.6 \%)$ were aged less than or equal to 20 years with the overall age range of 17 to 28 . More than half of the respondents $67(53.17 \%)$ were male. Concerning their academic year $75(59.52 \%)$ were $2^{\text {nd }}$ year and with regard to their department $81(64.3 \%$ ) were nursing students. Only $11(8.63 \%)$ of the students followed their preparatory education in rural areas whereas $33(26.19 \%)$ in semi-urban areas. With regard to their parents occupation $51(40.48 \%)$ and $7(5.56 \%)$ of the students reported that their fathers' occupation is government employee and daily laborer respectively, whereas $41(32.54 \%)$ reported their mothers occupation to be housewife. Majority, $119(94.4 \%)$ of the students replied that they are supported by their families. As it is seen from the Table 1 
below some of the students hesitate to report some of the variables, for example, 7(5.56\%) and 13(10.32\%) students did not reported the occupation of their fathers and mothers respectively and 2(1.59\%) and $14(11.11 \%)$ students did not reported about who support them and source of income of their supporters respectively.

Table 1. Socio-demographic characteristics of the students

\begin{tabular}{|c|c|c|c|}
\hline Variables & Categories & Frequency & Percentage \\
\hline \multirow[t]{2}{*}{ Age } & $\leq 20$ years & 67 & 53.17 \\
\hline & $>20$ years & 59 & 46.83 \\
\hline \multirow[t]{2}{*}{ Sex } & Male & 65 & 51.6 \\
\hline & Female & 61 & 48.4 \\
\hline \multirow[t]{3}{*}{ Academic year } & Two & 75 & 59.52 \\
\hline & Three & 51 & 40.48 \\
\hline & Total & 126 & 100 \\
\hline \multirow[t]{3}{*}{ Place where they learned preparatory } & Urban & 82 & 65.08 \\
\hline & Semi-urban & 33 & 26.19 \\
\hline & Rural & 11 & 8.73 \\
\hline \multirow[t]{2}{*}{ Department } & Nursing & 81 & 64.3 \\
\hline & Midwifery & 45 & 35.7 \\
\hline \multirow{6}{*}{ Occupation of fathers } & Farmer & 31 & 24.60 \\
\hline & Government employee & 51 & 40.48 \\
\hline & Daily laborer & 7 & 5.56 \\
\hline & NGO employee & 13 & 10.32 \\
\hline & Merchant & 11 & 8.73 \\
\hline & Total & 113 & 89.68 \\
\hline \multirow{7}{*}{ Occupation of the mothers } & Farmer & 16 & 12.70 \\
\hline & Government employee & 27 & 21.43 \\
\hline & Daily laborer & 4 & 3.17 \\
\hline & NGO employee & 18 & 14.29 \\
\hline & Housewife & 41 & 32.54 \\
\hline & Merchant & 7 & 5.56 \\
\hline & Total & 113 & 89.68 \\
\hline \multirow[t]{4}{*}{ Who Support you } & Family members & 119 & 94.4 \\
\hline & Relatives & 2 & 1.59 \\
\hline & Other & 3 & 2.38 \\
\hline & Total & 124 & 98.41 \\
\hline \multirow{4}{*}{ Income source of your supporter } & Salary & 63 & 50 \\
\hline & Farming & 19 & 15.08 \\
\hline & Merchant & 30 & 23.81 \\
\hline & Total & 112 & 88.89 \\
\hline
\end{tabular}

\subsection{Students' knowledge about active participation in the classroom}

We used eleven item questions to assess students' knowledge about benefits of active participation in the classroom. Accordingly, the responses of students to the question "What is/are the benefit/s of active participation in classroom?" indicate that $93(73.81 \%)$ of them replied it always add interest for students to learn, 87(69.05\%) said it always engage students in learning activities, 79(62.70\%) of them replied that it help students control what is happening in the class, 88(69.84\%) reported that active participation help students share their views, ideas and benefits about the content under discussion and 84(66.67\%) of the students said it give opportunity for students to practice using the language of the discipline. As it is seen in the following table in general, only few of the students undermine the benefits of active participation in classroom. For example, only $1(0.8 \%)$ student denied that active participation add interest for students, $1(0.8 \%)$ do not agree that active participation promote students preparation, and only $2(1.6 \%)$ of the students do not accept that active participation help students to share their views, ideas and beliefs about the content under study. The Table 2 shows for detail. 
Table 2. Perceived benefit/s of active participation in classroom among nursing and midwifery students

\begin{tabular}{|c|c|c|c|c|c|c|c|}
\hline \multirow[t]{2}{*}{ Sno } & \multirow{2}{*}{$\begin{array}{l}\text { What is/are the benefit/s of active participation in } \\
\text { classroom? }\end{array}$} & \multicolumn{6}{|c|}{ Response } \\
\hline & & No & $\%$ & No & $\%$ & No & $\%$ \\
\hline $\mathbf{1}$ & Adds interest to the student & 93 & 73.81 & 28 & 22.22 & 4 & 3.17 \\
\hline 2 & Engages students in a learning activity & 87 & 69.05 & 37 & 29.4 & 1 & 0.8 \\
\hline 3 & Provides teachers' feedback & 78 & 61.9 & 42 & 33.33 & 5 & 3.97 \\
\hline 4 & Provides students' feedback & 70 & 55.56 & 51 & 40.48 & 4 & 3.17 \\
\hline 5 & Promotes preparation on the previous assignment & 72 & 57.14 & 52 & 41.27 & 1 & 0.8 \\
\hline 6 & Controls what is happening in the class & 79 & 62.70 & 45 & 35.71 & 1 & 0.8 \\
\hline 7 & Balances who contributes in the class and how much & 67 & 53.17 & 50 & 39.68 & 8 & 6.35 \\
\hline 8 & Encourages dialogue among and between students & 67 & 53.17 & 50 & 39.68 & 8 & 6.35 \\
\hline 9 & Helps students to develop important speaking skills & 75 & 59.52 & 45 & 35.71 & 5 & 3.97 \\
\hline 10 & $\begin{array}{l}\text { Gives students the opportunity to practice using the } \\
\text { language of the discipline }\end{array}$ & 84 & 66.67 & 35 & 27.78 & 6 & 4.76 \\
\hline 11 & $\begin{array}{l}\text { Helps students share views, ideas and beliefs about } \\
\text { the content under discussion }\end{array}$ & 88 & 69.84 & 35 & 27.78 & 2 & 1.6 \\
\hline
\end{tabular}

As it is seen in the following pie chart 106(84.13\%) of the students had good knowledge about the benefits of active participation in the classroom, illustrated in Figure 1.

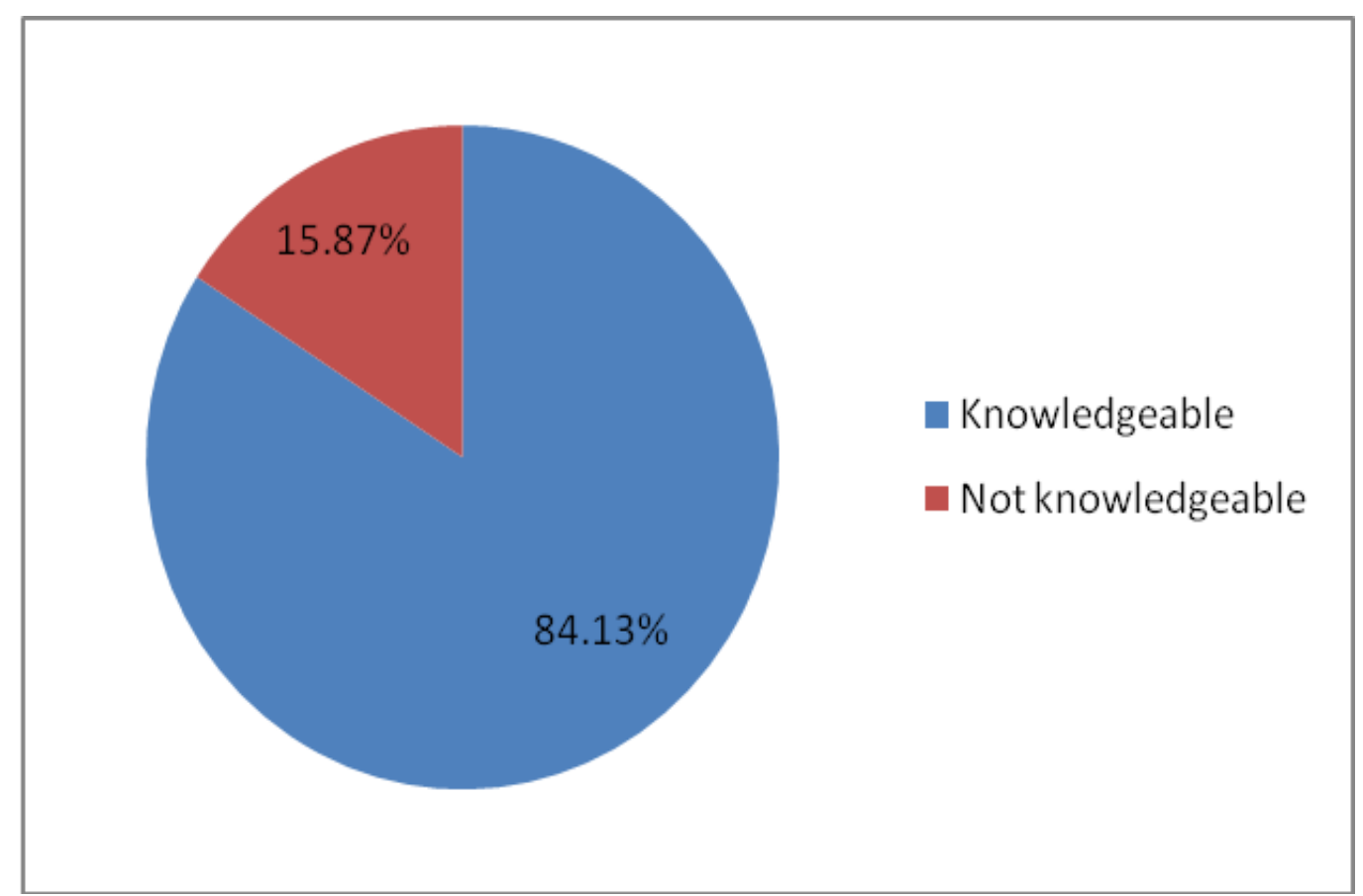

Figure 1. Overall level of knowledge about the benefits of active participation in the classroom among nursing and midwifery students.

\subsection{Perceived reasons why students do not actively participate in the classroom}

When we see the students response for the question "What are the reasons why students do not participate in the classroom?" $17(13.49 \%)$ and $19(15.08 \%)$ respectively replied very high and high that they (students) don't know the language, 21(16.67\%) and 15(11.90\%) respectively replied very high and high that they fear other students, $22(17.46 \%)$ and $54(42.86 \%)$ of the students replied very high and very low that they are very busy doing other learning activities respectively. In addition, 6(4.76\%) and 41(32.54\%) of the respondents replied very high and very low that teacher doesn't give them an opportunity to talk respectively and $19(15.08 \%)$ and $36(28.57 \%)$ of the students replied very high and very low that they fear teachers face when s/he looks at them respectively. The Table 3 shows for detail. 
Table 3. Perceived reasons why students do not actively participate in the classroom among nursing and midwifery students

\begin{tabular}{|c|c|c|c|c|c|c|c|c|c|c|}
\hline \multirow{2}{*}{$\begin{array}{l}\text { What are the reasons why } \\
\text { students do not participate in } \\
\text { the classroom? }\end{array}$} & \multicolumn{2}{|c|}{ Very high } & \multicolumn{2}{|c|}{ High } & \multicolumn{2}{|c|}{$\begin{array}{l}\text { Response } \\
\text { Moderate }\end{array}$} & \multicolumn{2}{|c|}{ Low } & \multicolumn{2}{|c|}{ Very low } \\
\hline & No & $\%$ & No & $\%$ & No & $\%$ & No & $\%$ & No & $\%$ \\
\hline $\begin{array}{l}\text { I don't know the language } \\
\text { very well }\end{array}$ & 17 & 13.49 & 19 & 15.08 & 43 & 34.1 & 20 & 15.87 & 26 & 20.6 \\
\hline I fear other students & 21 & 16.67 & 15 & 11.9 & 32 & 25.4 & 19 & 15.08 & 38 & 30.2 \\
\hline $\begin{array}{l}\text { I am afraid I might ask } \\
\text { wrong question or give wrong } \\
\text { answer }\end{array}$ & 27 & 21.43 & 25 & 19.8 & 30 & 23.8 & 22 & 17.46 & 21 & 16.67 \\
\hline I don't know what to say & 18 & 14.29 & 13 & 10.32 & 29 & 23.0 & 29 & 23.0 & 36 & 28.6 \\
\hline $\begin{array}{l}\text { My parents told me not stand } \\
\text { to talk in front of people }\end{array}$ & 11 & 8.7 & 9 & 7.14 & 26 & 20.6 & 18 & 14.29 & 61 & 48.41 \\
\hline $\begin{array}{l}\text { I am very busy doing other } \\
\text { learning activities }\end{array}$ & 22 & 17.46 & 9 & 7.14 & 26 & 20.6 & 14 & 11.1 & 54 & 42.9 \\
\hline $\begin{array}{l}\text { I cannot stand on my feet } \\
\text { because my desk is very close }\end{array}$ & 22 & 17.46 & 8 & 6.3 & 23 & 18.3 & 7 & 5.6 & 65 & 51.6 \\
\hline $\begin{array}{l}\text { I already know what the } \\
\text { teacher is teaching }\end{array}$ & 13 & 10.32 & 33 & 26.19 & 32 & 25.4 & 10 & 7.9 & 37 & 29.4 \\
\hline $\begin{array}{l}\text { I can't easily understand } \\
\text { what the teacher is teaching }\end{array}$ & 17 & 13.49 & 8 & 6.3 & 40 & 31.7 & 19 & 15.08 & 41 & 32.5 \\
\hline $\begin{array}{l}\text { I cannot answer the } \\
\text { assignments the teacher gives }\end{array}$ & 12 & 9.52 & 20 & 15.87 & 28 & 22.2 & 13 & 10.32 & 52 & 41.3 \\
\hline $\begin{array}{l}\text { Teacher doesn't give me an } \\
\text { opportunity to talk }\end{array}$ & 6 & 4.8 & 15 & 11.9 & 33 & 26.19 & 30 & 23.8 & 41 & 32.5 \\
\hline $\begin{array}{l}\text { Teacher spends lot of time in } \\
\text { the class making me feel } \\
\text { bored }\end{array}$ & 18 & 14.29 & 15 & 11.9 & 25 & 19.8 & 34 & 27.0 & 33 & 26.19 \\
\hline $\begin{array}{l}\text { I fear teachers face when s/he } \\
\text { looks at me }\end{array}$ & 19 & 15.08 & 18 & 14.3 & 36 & 28.6 & 16 & 12.7 & 36 & 28.6 \\
\hline
\end{tabular}

\subsection{Suggested strategies to be used by the regular classroom teachers to increase students' participation} In this study we utilized a question containing 18 items all filled in five point Likert Scale. More than half, $70(55.56 \%)$ of the respondents suggest that teachers must consider the convenience of the classroom environment before the class discussion started, 69(54.76\%) of them suggest that teachers should let students teach each other, another $69(54.76 \%)$ of the students suggest teachers should devise activities that elicit participation. More than half 75(59.5\%) and 71(56.3\%) of the students suggest that teachers should ask students to assess their own participation and teach students skills needed to participate respectively. Majority of the respondents $103(81.8 \%)$ suggest that regular classroom teachers should make the content fit to the available time to make active participant in their classroom. From the total students 20(15.9\%) do not agree that teachers need to assess students' prior knowledge to implement appropriate learning methods and 46(36.5\%) do not want to be busy by teachers/classroom activities. The Table 4 shows for detail. 
Table 4. Strategies suggested to be used by the regular classroom teachers to increase students' participation in the classroom

\begin{tabular}{|c|c|c|c|c|c|c|c|c|c|c|}
\hline \multirow{2}{*}{$\begin{array}{l}\text { What strategies do you suggest to be } \\
\text { used by the regular classroom } \\
\text { teachers to increase students' } \\
\text { participation? }\end{array}$} & \multicolumn{2}{|c|}{ Very high } & \multicolumn{2}{|c|}{ High } & \multicolumn{2}{|c|}{$\begin{array}{l}\text { Response } \\
\text { Moderate }\end{array}$} & \multicolumn{2}{|c|}{ Low } & \multicolumn{2}{|c|}{ Very low } \\
\hline & No & $\%$ & No & $\%$ & No & $\%$ & No & $\%$ & No & $\%$ \\
\hline $\begin{array}{l}\text { Consider the convenience of the } \\
\text { classroom environment before the } \\
\text { class discussion }\end{array}$ & 55 & 43.7 & 15 & 11.9 & 37 & 29.4 & 11 & 8.7 & 6 & 4.8 \\
\hline Assess students prior knowledge & 43 & 34.1 & 30 & 23.8 & 31 & 24.6 & 14 & 11.1 & 6 & 4.8 \\
\hline $\begin{array}{l}\text { Devise activities that elicit } \\
\text { participation }\end{array}$ & 36 & 28.6 & 33 & 26.2 & 34 & 27.0 & 14 & 11.1 & 7 & 5.6 \\
\hline Use jigsaw/game approach & 31 & 24.6 & 26 & 20.6 & 36 & 28.6 & 20 & 15.9 & 11 & 8.7 \\
\hline Keep the students busy & 13 & 10.3 & 32 & 25.4 & 33 & 26.2 & 22 & 17.5 & 24 & 19.0 \\
\hline $\begin{array}{l}\text { Foster an ethos of participation } \\
\text { (collective contribution of ideas) }\end{array}$ & 32 & 25.4 & 41 & 32.5 & 22 & 17.5 & 21 & 16.7 & 8 & 6.3 \\
\hline $\begin{array}{l}\text { Ensure that everyone's } \\
\text { contributions are audible }\end{array}$ & 39 & 31.0 & 27 & 21.4 & 38 & 30.2 & 13 & 10.3 & 7 & 5.6 \\
\hline Let students teach each other & 45 & 35.7 & 24 & 19.0 & 29 & 23.0 & 17 & 13.5 & 9 & 7.1 \\
\hline Allow anonymous questions & 33 & 26.2 & 27 & 21.4 & 32 & 25.4 & 23 & 18.3 & 9 & 7.1 \\
\hline Give students a voice and a choice & 59 & 46.8 & 23 & 18.3 & 23 & 18.3 & 10 & 7.9 & 9 & 7.1 \\
\hline $\begin{array}{l}\text { Place the emphasis on students' } \\
\text { ideas }\end{array}$ & 41 & 32.5 & 31 & 24.6 & 28 & 22.2 & 17 & 13.5 & 7 & 5.6 \\
\hline $\begin{array}{l}\text { Redirect questions and answers to } \\
\text { other students (whole class) }\end{array}$ & 39 & 31.0 & 32 & 25.4 & 23 & 18.3 & 19 & 15.1 & 11 & 8.7 \\
\hline $\begin{array}{l}\text { Ask students to assess their own } \\
\text { participation }\end{array}$ & 40 & 31.7 & 35 & 27.8 & 29 & 23.0 & 12 & 9.5 & 8 & 6.3 \\
\hline Provide enough praising responses & 41 & 32.5 & 29 & 23.0 & 31 & 24.6 & 17 & 13.5 & 6 & 4.8 \\
\hline $\begin{array}{l}\text { Teach students skills needed to } \\
\text { participate }\end{array}$ & 43 & 34.1 & 28 & 22.2 & 26 & 20.6 & 21 & 16.7 & 6 & 4.8 \\
\hline $\begin{array}{l}\text { Keep the content bite-sized to fit the } \\
\text { available time }\end{array}$ & 51 & 40.5 & 20 & 15.9 & 32 & 25.4 & 14 & 11.1 & 7 & 5.6 \\
\hline
\end{tabular}

3.5. Cross-tabulation to see the presence of associations between sociodemographic variables and knowledge about active participation in classroom.

We have conducted cross tabulation and Pearson chi-square test to see the association between students' knowledge and socio-demographic characteristics. Accordingly we run the cross-tabulation for age, sex, academic year, place of origin, department, father and mother occupation and who support them. Finally only students' academic year has shown statistically significant association with their knowledge about the benefit of active participation in the classroom at $95 \%$ confidence interval and P-value of less than 0.05 . The Table 5shows for detail.

Table 5. Cross-tabulation between students' knowledge and socio-demographic characteristics

\begin{tabular}{|c|c|c|c|c|c|}
\hline \multirow[t]{2}{*}{ Variables } & \multirow[t]{2}{*}{ Categories } & \multicolumn{2}{|c|}{ Knowledge } & \multicolumn{2}{|c|}{ Chi-square } \\
\hline & & Not Knowledgeable & Knowledgeable & $\mathbf{X}^{2}$ & P-value \\
\hline \multirow[t]{2}{*}{ Age } & $\leq 20$ & 13 & 52 & 1.7125 & .1907 \\
\hline & $>20$ & 7 & 54 & & \\
\hline \multirow[t]{2}{*}{ Sex } & Male & 9 & 56 & .4131 & .5204 \\
\hline & Female & 11 & 50 & & \\
\hline \multirow[t]{2}{*}{ Academic year } & Second & 15 & 50 & 5.2179 & $.02236 *$ \\
\hline & Third & 5 & 56 & & \\
\hline \multirow[t]{3}{*}{ Place of origin } & Urban & 17 & 63 & 2.9834 & .2250 \\
\hline & Semi-urban & 3 & 30 & & \\
\hline & Rural & 1 & 10 & & \\
\hline \multirow[t]{2}{*}{ Department } & Nursing & 13 & 68 & 0.0622 & 0.8030 \\
\hline & Midwifery & 8 & 37 & & \\
\hline Occupation of their & Farmer & 2 & 28 & 6.2571 & 0.09975 \\
\hline \multirow[t]{3}{*}{ fathers } & Gov't Employee & 14 & 37 & & \\
\hline & Daily Laborer & 1 & 6 & & \\
\hline & Others\# & 4 & 26 & & \\
\hline \multirow{4}{*}{$\begin{array}{l}\text { Occupation of their } \\
\text { mothers }\end{array}$} & Farmer & 5 & 10 & 5.2112 & .1570 \\
\hline & Gov't Employee & 6 & 21 & & \\
\hline & Housewife & 4 & 37 & & \\
\hline & Other\$ & 4 & 26 & & \\
\hline \multirow{2}{*}{$\begin{array}{l}\text { Who support them } \\
\text { (the students) }\end{array}$} & Family members & 19 & 99 & .0535 & .8170 \\
\hline & Others & 1 & 4 & & \\
\hline
\end{tabular}

${ }^{\#}$ Merchants, NGO employee, ${ }^{\$}$ merchants, NGO employee, daily laborer 


\section{DISCUSSION}

In this study majority of the students $93(73.81 \%), 87(69.05 \%), 79(62.70 \%)$ and $88(69.84 \%)$ replied that active participation classroom add interest for students to learn, engage students in learning activities, help students control what is happening in the class and help students share their views, ideas and benefits about the content under discussion respectively. This is supported by other studies which reveal that students' interaction and active participation in the classroom is crucial for achieving effective learning and teaching process [2] contributes to learning \& motivates students to learn $[4,5]$ and is fundamental action to achieve effective learning and plays significant role in the success of academic and personal development of students [6].

Regarding the reason why students do not participate in their classroom this study revealed that 36 (28.57\%), $36(28.56 \%)$, and 22(17.46\%) of the respondents replied that students don't know the language of interaction in the classroom, they fear other students and they are very busy doing other learning activities respectively. In addition, $6(4.76 \%)$ of the students said teachers didn't give them an opportunity to talk and $19(15.08 \%)$ report that they fear teachers face when s/he looks at them. This is similar with other study which depicted important factors that affect students' active participation in classroom is the characters and skills of the lecturer. Teachers/lecturers' characters such as being supportive, understanding, approachable, giving smiles and nodding for admitting the answers that are given by students, affirmative and open-mindedness are among the encouraging factors [12].

Concerning the possible suggestion made by students $70(55.56 \%), 69(54.76 \%), 69(54.7 \%)$ and $75(59.5 \%)$ suggest that teachers must consider the convenience of the classroom environment before the class discussion started, should let students teach each other, devise activities that elicit participation and should ask students to assess their own participation respectively. This result is supported by another study that revealed engaging the students in classroom activities provides them opportunity to receive input from fellow students, to apply their knowledge and to enhance public speaking skills and it also help teachers to get a more accurate idea about the understanding level of students on the concept he/she is teaching [16]. Currently, Ministry of education (MOE) of Ethiopia advocates the interactive type of learning i.e. use of active learning methods to help students interact with their environment and discuss issues with their colleagues freely.

\section{CONCLUSION}

This study was focusing on assessing students' knowledge about active participation in classroom and identifying suggested strategies to be used by regular classroom teachers to improve students' participation. Accordingly, as it is indicated in the result majority of the students had good knowledge about the benefit of active participation in classroom though not practicing it adequately. The students also depicted the reasons why students do not actively participate in classroom. Majority of the students highly recommended eighteen (18) strategies to be utilized by the regular classroom teachers to help students actively participate in classrooms.

Based on the finding of this study we strongly recommend the following points for concerned bodies. As it is known the government/ministry of education's direction is to make students critical thinkers, rationale and productive society. Therefore to achieve this goal the contribution of regular classroom teachers is of paramount significance in shaping the students and improving their classroom participation. Students who are active participant in their classroom will develop their sense of self-esteem, self-confidence, communication skill, and also productivity, therefore, teachers should use the suggested and other strategies used to improve students' classroom participation. Department/school heads should regularly follow the activities of regular classroom teachers and encourage them to use active teaching methods. Students should be motivated to be active participant in their classroom and they should be committed and self-confident to participate as free as possible. The universities should minimize the number of students per class and make classroom environment convenient for implementation of active teaching - learning methods. Course delivery method should also be semester based rather than block course to give students and teachers enough time for preparation and implementation of active learning methods.

As both departments/disciplines require active engagement of the students during their study period to be equipped with necessary knowledge and skill needed to meet professional expectations. This study is extremely important to give insight for nursing and midwifery instructors to use active learning methods that make their students active participant in teaching learning process. 


\section{ACKNOWLEDGEMENTS}

The authors of this study would like to forward our deepest gratitude to Jimma University for facilitating situations to undertake this study. We also want to thank nursing and midwifery students for their willingness to participate in the study.

\section{REFERENCES}

[1] Abdullah, Mohd.Y,Bakar, N.R.A, and Mahbob, M.H, "Student's participation in classroom: what motivates them to speak up?" Procedia-Soc. Behav. Sci, vol. 51, pp. 516-522, 2012.

[2] Abdullah, Mohd Yusof, Noor Rahamah Abu Bakar, and Maizatul Haizan Mahbob, "The dynamics of student participation in classroom: observation on level and forms of participation," Procedia-Social and Behavioral Sciences, vol. 59, pp. 61-70, 2012.

[3] Liu, J, Asian students' classroom communication patterns in U.S. universities: an emic perspective. Westport, CT: Greenwood Publishing Group, Inc.2001.

[4] ZainalAbidin bin Sayadi, An investigation into first year Engineering students' oral classroom participation: a case study.UniversitiTeknologi Malaysia, 2007.

[5] Helen Patrick, "Motivational Influences on Student Participation in Classroom Learning Activities,"Teachers college record, vol. 106, no. 9, pp. 1759-1785,2004.

[6] SitiMaziha Mustapha,"Understanding classroom interaction: a case study of international students' classroom participation at one of the colleges in Malaysia,"International Journal for the Advancement of Science \& Arts, vol. 1, no. 2,pp. 91-99, 2010.

[7] Pajares, F, "Assessing self-efficacy beliefs and academic success: the case for specificity and correspondence,"Paper presented at the Annual Meeting of the American Educational Research Association, New York, 1996.

[8] Mahyuddin, Rahil, Rahil Mahyuddin, Habibah Elias, Loh Sau Cheong, Muhd Fauzi Muhamad, Nooreen Noordin and Maria Chong Abdullah," The relationship between students' self-efficacy and their achievement," Jurnal Pendidik dan. Pendidikan, vol. 21, pp. 61-71, 2006.

[9] Mustapha, Siti Maziha, Nik Suryani Nik Abd Rahman, and Melor Md Yunus, "Factors influencing classroom participation: a case study of Malaysian undergraduate students," Procedia-Social and Behavioral Sciences, vol. 9, pp. 1079-1084, 2010.

[10] Fassinger, P. A, "Professors' and students' perception of why students participate in class,"Teaching Sociology, vol. 24, no. 1, pp. 25-33, 1996.

[11] Sayadi, Zainal Abidin. An investigation into first year engineering students' oral classroom participation: a case study. Diss. Universiti Teknologi Malaysia, 2007. [Online] Available: https://www.researchgate.net/publication/49910192

[12] Dallimore, E. J, Hertenstein, J. H, and Platt, M. B, "Classroom participation and discussion effectiveness: studentgenerated strategies,"Communication Education,vol. 53, no. 1, pp. 103-115, 2004.

[13] Akpan JP and Beard LA, "Using Constructivist Teaching Strategies to Enhance Academic Outcomes of Students with Special Needs," Universal Journal of Educational Research, vol. 4, no. 2, pp. 392-398, 2016

[14] Smith, D. H, "Developing a more interactive classroom: A continuing odyssey,"Teaching Sociology, vol. 24, no. 1, pp. 64-75, 1996.

[15] Karp, D. A and Yoels, W. C, "The college classroom: Some observations on the meanings of student participation," Sociology \& Social Research, vol. 60, no. 4, pp. 421-439, 1976.

[16] Bean, John C and Dean E. Peterson. "Grading classroom participation," New Directions for Teaching and Learning, no. 74, pp. 33-40, 1998

[17] Zhao, C. M, "Factors influencing student participation in classroom interaction," Higher Education of Social Science, vol. 11 , no. 3, pp. 20-23, 2016.

[18] Howard, J. R and Baird, R, "The consolidation of responsibility and students' definitions of situation in the mixedaged college classroom,"Journal of Higher Education, vol. 71, no. 6, pp. 700-721, 2000.

[19] Kasa Y, "Improving Student's Participation in the Classroom in Chemistry Freshman Students at Assosa University: An Experimental Action Research,"International Journal of Education, Culture and Society, vol 1, no1, pp. 5-10, 2016.

[20] Abdullah MY, Bakar NR, Mahbob MH,"Student's participation in classroom: What motivates them to speak up?,"Procedia-Social and Behavioral Sciences, vol. 1, no. 51, pp. 516-22, Jan 2012.

[21] Ravi Chandran,"Mandatory class participation: Factors that influence, classroom practices and learning outcomes," Asian Journal of the Scholarship of Teaching and Learning, vol. 5, no. 2, pp. 108-122, 2015.

[22] Green D, "Class participation in a teacher training college: What is it and what factors influence it," English Language Teacher Education and Development, vol. 11, pp. 15-26. 2008

[23] Tesfaye D and G/Tsadik D, "Causes of Students' Limited Participation in EFL Classroom: Ethiopian Public Universities in Focus, "Inter.J.Edu.Res.Technol, vol. 6, no. 1, pp. 74-89, Mar 2015.

[24] Worako AW, "Enhancing the classroom participation: The Case of 2nd Year Students of Water Resources and Irrigation Management (BSc) at Dilla University," International Journal of Humanities and Social Science, vol. 8, no. 4, pp. 10-17, 2018.

[25] Howard, J. R, Short, L. B, and Clark, S. M, "Students' participation in the mixed-age college classroom," Teaching Sociology, vol. 24, no. 1, pp. 8-24, 1996. 
[26] Fassinger, P. A, "How classes influence students' participation in college classrooms,"Journal of Classroom Interaction, vol. 35, no. 2, pp. 38-47, 2000.

\section{BIOGRAPHIES OF AUTHORS}
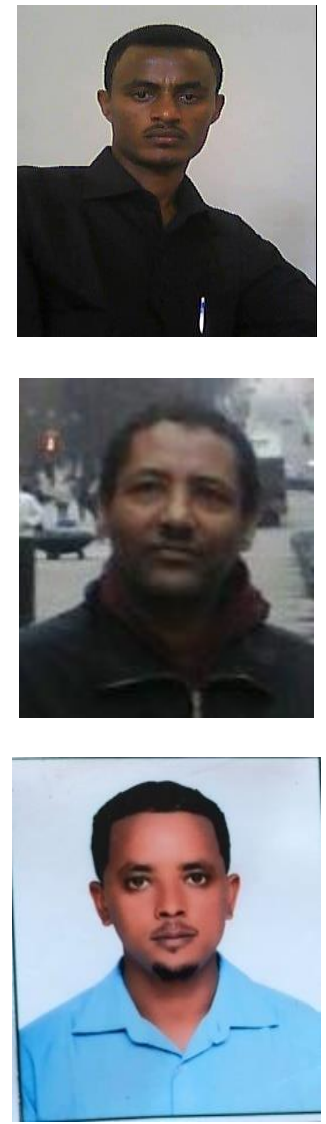

Abebe AberaTesema was born in 1985 G.C. at rural village called Warasole at western part of Ethiopia. He graduates his bachelor science degree in nursing at Hawasa University of Ethiopia in 2007. He takes hismasters degreein Adult Health Nursing at Jimma University of Ethiopia in 2011G.C. Now, he is Assistant Professor at Jimma University school of Nursing and midwifery. He has been actively researching and publishing his research since 2013. This man has been published his research articles in various international repeutablejournals.He is a primary author of this article. His contact addressis abeef2011@gmail.com

Ebrahim Yimam Reta was born in 1963 G.C. in northern part of Ethiopia. He graduates his bachelor science degree in nursing at Jimma University of Ethiopia in 1998. He takes his masters degree in Adult Health Nursing at Addis Ababa University, Ethiopia in 2008 G.C. Now, he is Assistant Professor at Jimma University school of Nursing and midwifery. He has been actively researching and publishing his research since 2015 . This man has been published his research articles in various international repeutable journals. His contact address is i_yimam2005@yahoo.com

Sheka Shemsi Seid was born in 1989G.C. at West Arsi Zone at South Eastern part of Ethiopia. He graduates his bachelor science degree in nursing at Jimma University of Ethiopia in 2013G.C. Furthermore, he takes his masters degree in Pediatrics and child Health at Addis Ababa University of Ethiopia and finished it in 2016. Now, he is Lecturer at Jimma University school of Nursing and midwifery and attending his second masters in emergency and critical care nursing which organized by Erasmus Mandusscholarship program in four different European Universities. He has been actively involved in different research activities and publishing his research since 2016. This man has been published his research articles in various international repeutable journals. His contact address is shekaa2006@gmail.com 